\title{
Forward Chaining Algorithm to Identify Haid and Istihadhah based on Quran-Hadith
}

\author{
$1^{\text {st }}$ Wisnu Uriawan ${ }^{1}, 2^{\text {nd }}$ Dian Sa'adillah Maylawati ${ }^{2}, 3^{\text {rd }}$ Wahyudin Darmalaksana $^{3}$,

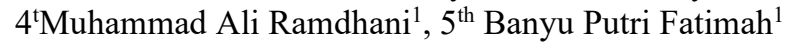 \\ \{wisnu_u@uinsgd.ac.id¹,dsaadillah@sttgarut.ac.id², yudi_darma@uinsgd.ac.id ${ }^{3}$, \\ m_ali_ramdhani@uinsgd.ac.id ${ }^{1}$, banyuputt@gmail.com ${ }^{1}$ \} \\ UIN Sunan Gunung Djati, Department of Informatics, Bandung, Indonesia ${ }^{1}$, Sekolah Tinggi \\ Teknologi, Department of Informatics, Garut - Indonesia ${ }^{2}$, UIN Sunan Gunung Djati, Department of \\ Hadith, Bandung, Indonesia ${ }^{3}$
}

\begin{abstract}
One of Muslim woman is lack of knowledge about distinguish haid or menstrual blood and istihadhah blood. A lot of women who are still confused and do not know the rules from Quran and Hadith in this regard. In addition, many people do not know about the term of istihadhah and how to define it. This study aims to build application that can help people, especially Muslim woman, to identify haid and istihadhah clearly. We used forward chaining algorithm in this study, because it is simple and considered suitable for determining the identification of haid and istihadhah and also because the facts, rules, and goals have been clearly defined.We tested our system with questionnaire of 50 respondents. The result showed that $86 \%$ of haid and istihadhad cases was correctly identify.
\end{abstract}

Keywords: forward chaining, haid, istihadhah

\section{Introduction}

Menstrual period for women is important. Especially for Muslim women, menstrual periods affect their worship activities. Many women are still confused to distinguish menstrual blood and istihadhah blood. Haidin the meaning of language is "flowing". As for the shari'a, haid or menstruation is the blood that comes out from the inside of a woman's womb at certain times that is known, not because of illness or calamity, but a natural state created by God in woman[1], [2]. While, istihadhahis blood that goes outside the days of menstruation and childbirth, not with good causes (a disease) that out from the womb. There are several factors and differentiation of menstrual blood and istihadhah blood, either based on the type and color of blood, the time of blood discharge, the duration of blood, and so forth.

With Information System (IS) in this era, knowledge of menstruation and istihadhah can be stored and accessed at any time. IS is a combination of information technology and human activity that uses computerized technology [3]. Information system is a system that processes data in an organized way[4], information system has a high level of flexibility that allows development into a better system[5]. Based on many research findings, the information system has advantages in terms of: good data accessibility[6], time efficience[3], accuracy [7], supporting decision appropriately [8],efficient/ low cost[9], broad accessibility[10], improving 
user understanding[11],increasing productivity[12], providing good data and information[13], and used as data storage media[14].

Implementation of IS canhelp women to identify menstrual blood andistihadhah with accurate and detailed. This certainly helps dispel doubts whether a woman is having menstruation or istihadhah. So, this study this study utilizes technology with Forward Chaining algorithm to identify menstruation and istihadhah. Forward Chaining is a rule-based algorithm that is simple and easy to implement[15][16]. Many studies use Forward Chaining to solve problems, such as decision support[17], [18], predicting a case study[19], [20], expert systems[21], [22], and so on. The level of accuracy that produced by the forward chaining algorithm is also quite high, depending on whether the rules are given have been completed or not yet. Because Forward Chaining requires clear rules and goals. Based on previous research, there are no research that spesific to build the system to solve and identify about haid and istihadhah.

Haid and Istihadhah are identified and grouped into 7 categories, among others[1]: Mubtadiah Mumayyizah, Mubtadiah Ghoiru Mumayyizah, Mu'tadah Mumayyizah, Mu'tadah Ghoiru Mumayyizah Dzakirotun Li Adatiha Qodron Wa Waqtan, Mu'tadah Ghoiru Mumayyizah Nasiyatun Li Adatiha Qodron Wa Waqtan, Mu'tadah Ghoiru Mumayyizah Dzakirotun Li Adatiha Qodron La Waqtan, and Mu'tadah Ghoiru Mumayyizah Dzakirotun Li Adatiha Waqtan La Qodron. For each categorywill be explained completely including with its laws based on the Quran and Hadithin Section II.

\section{Research Methodology}

This research is a conceptual design that developed from prototype of information system for the identification of menstruation and istihadhah. Systematics and design stages use the Research and Development (R\&D) model with the final product of software. The design of prototype is limited to conceptual design. R\&D model is dominant applied for technology develoment[23] that have 3 activities, among others basic research, applied research, and development research. In this study, knowledge about menstruation and istihadhah is used as basic research, and for applied research we have Forward Chaining algorithm for identifying haid and istihadhah. Then, in development we used software engineering with object oriented analysis and design, because it is powerfull modeling [24]-[27].

\section{Result and Discussion}

\subsection{Understanding Haid and Istihadhah based on Quran-Hadith}

With information technology in this era, knowledge of menstruation and istihadhah can be stored and accessed at any time. Included in helping women to identify menstrual blood andistihadhah with accurate and detailed. This certainly helps dispel doubts whether a woman is having menstruation or istihadhah.According to the Quran, Surah al-Baqarah verse 222 which means: "And they ask you about menstruation: say, "It is harmful, so keep away from women during menstruation. And do not approach them until they have become pure. Once they have become pure, approach them in the way God has directed you." God loves the repentant, and He loves those who keep clean. "', explains that menstruation is dirty blood that 
naturally comes out of a woman's womb. This verse shows that God gives clues about the period of menstruation that ends after the sacred, that is after the dry and the cessation of blood. Not depending on the number of days. So that, the basis of law or benchmark is the presence of Haid's blood itself. If there are blood and its nature so it is a menstruation, then apply the law of menstruation. But if not found blood or its nature is not menstrual blood, then do not apply menstrual law to her.Shaykh Ibn Utsaimin added that if there is indeed a certain day limit in the period of menstruation, there must be from the Quran and Hadith that explain this.Shaykh Islam Ibn Taimiyahsaid: "In principle, every blood that comes out of the womb is menstruation. Unless there is evidence to suggest that the blood is Istihadhah."[28].

The limit of time period of menstruation is also explained according to the Shafi'iyah Ulama the minimum period of menstruation is a day and night, and the maximum limit is 15 days. If more than 15 days then blood is Istihadhah blood and obligatory for the woman to bathe and pray. Meanwhile, Imam Ibn Taimiyah in Majmu' Fatawa said that there is no definite limit on the minimum and maximum period of menstruation. And this opinion is the most powerful and the most reasonable, and agreed by most scholars, including Shaykh Ibn Uthaimin also took this opinion. The indicator of the completion of menstrual period is the presence of white clots or mucus (such as whiteness) that comes out of the way of the uterus. However, if you do not find any white mucus, it can be checked with white cotton is inserted into the vagina. If the cotton does not contain any spots, and is completely clean, it is mandatory to take a bath and pray. The law of women who are menstruating according to Islamic law, among others: forbidden at the time of menstruation to have sex, forbidden menstruating women to perform prayers and fasting, forbidden women menstruation do thawaf in Ka'ba, and and some other law that there are differences of opinion among fiqh scholars and return to the understanding and belief respectively.

Meanwhile, istihadhah is a blood that comes out of the habit, which is not in the period of menstruation and not also due to childbirth so often referred to as blood disease. Imam Nawawi in Sharah Muslim said that istihadhah is a blood flowing from the female genitals that are not in time. Women who experience istihadhah matters become vague because of the similarity between menstrual blood and istihadhah. If the blood comes out of it continuously or for a long time it will be difficult to determine when the time is considered as the period and when the time is considered as istihadhah period, where prayer and fasting are not abandoned because of it.

The color of blood coming out of a woman's womb also affects the identification between menstruation and istihadhah. The color of the blood include: dark red (dark brown), red, yellowish red, yellow, and yellow whitish (cloudy). Dark Red Blood (Old Brown) is strong blood. Red blood is weak when compared to blood Blackish black (brown old), and strong when compared to yellowish red blood. Yellow blood is stronger than Yellow blood. Yellow blood is stronger than yellowish white blood (Snoring).

In terms of circumstances Istihadhah divided into 7 Groups, following the name of the class and its explanation:

1. Mubtadiah Mumayyizah is the first woman to menstruate and able to distinguish the blood of both nature and color. The laws are the strong blood (see color difference) is menstruation, the weak blood is Istihadhah. With detail conditions, among others: strong blood is not less than the minimum limit of menstruation (more or more 24 hours), strong blood does not exceed the maximum limit of menstruation (15 days, 15 nights), weak blood is no less than the sacred minimum (15 days, 15 nights), or weak blood must be continuous (unbroken). If one of the those conditions does not exist, then it can not be classified to Mumayyizah.For example: there was a woman 
who thatthe blood flow for the first time for 20 consecutive days, 3 days red blood black (strong blood) and 17 days red blood (weak blood). So we can identify that the menstruation period is 3 days, and the istihadhah is 17 days. Another example, there is a woman has black blood for 5 days, yellow blood for 17 days, and black blood again for 6 days. So, the menstruation period is 5 days, Istihadhah is 17 days and menstruation again for 6 days.

2. Mubtadiah Ghoiru Mumayyizah is category for a women who first menstruate who are not able to distinguish blood either nature or color. The law is when she knows or remember the first time her blood flowed, then the menstruation is 1 day 1 night (24 hours), and the sacred for the next days. But, if she does not know or remember herblood flowed time, then she is categorized asd Mutahayiroh.For example: women come out blood for 17 days with the same color and nature. So, it can be punished menstruation 1 day 1 night, else is Istihadhah.Alternatively, the woman bleeds as follows:20 days of red blood and yellow blood 6 days. Because of the red strong blood longer than the maximum limit of menstruation (15 days 15 nights), then her first menstrual is 1 day and istihadhahis 25 days later.

3. Mu'tadah Mumayyizahwhen a women who regularly menstruate and are able to distinguish blood either nature or color. The law is strong blood of menstruation, weak blood of istihadhah. Even though, contrary to her menstrual habits. For example, women have a habit of bleeding for 5 days at the beginning of each month ( 1 to 5 ). And in the other month he was out blood for 25 days, with dark red blood for 10 days and red blood 15 days, so that the mentruation is 10 days (due to strong blood) and Istihadhah is 15 days.Or, the woman has had menstruation experience as follows: yellow blood for 12 days and red blood 7 days, so the menstruation is 7 days and the istihadhah is 12 days. In Mu'tadah Mumayyizah, determination of menstruation with a look of strong blooddid not look at the history og mentruation of the month before.

4. Mu'tadah Ghoiru Mumayyizah Dzakirotun Li Adatiha Qodron Wa Waqtan, is for a women who do not able to distinguish blood but remember the first time and duration of menstrual habits. The law is returned to custom and time, it means that it can be judged by the habit in the previous month. For example, the women usually menstruate for 7 days at every beginning of the month. This month she bleeds for 17 days. She also can not distinguish the color of blood, or his blood comes out with 1 color. So we can identify that her menstruation is 7 days because in equated with the previous month's curiosity, and the last 10 days is istihadhah.

5. Mu'tadah Ghoiru Mumayyizah Nasiyatun Li Adatiha Qodron Wa Waqtan, women who have been menstruating and forget the customs or habits both the duration and the begining of mentruation.For example: a woman who bleeds for 20 days and her blood can not be distinguished, it means that her blood is only 1 color, or blood can be distinguished but can not be identifiedbecause she forgot about menstruation also its time. The law for her the menstrual law in the matter of the forbidden, such as have a sex, but the sacred law in the matter of Obligation (Salat, fasting, thawaf, thalaq, i'tikaf, and must take a bath every do those obligation).

6. Mu'tadah Ghoiru Mumayyizah Dzakirotun Li Adatiha Qodron La Waqtan, for a women who have been menstruating and sacred, and also remember the customs or habits for menstruation duration but not remenber for the beginning of menstruation time. For example: a womenusually menstruate for 5 days in the first 10 days and she does not know the start. But she knows and believes that the first day she was holy. 
And this month she came out full blood for a month. So the law is in the sixth day is menstruation, for firstday is not menstruation same as the last 20 days.As for the second day until the fifth day there is a possibility can be menstruation or can be not. Likewise, for seventh day to tenth there is a possibility like that too (can be menstruation or can not be).

7. Mu'tadah Ghoiru Mumayyizah Dzakirotun Li Adatiha Waqtan La Qodronis for a woman who has been menstruating and remember its start time but not with the time duration. For example: there is a woman who usually menstruate at the beginning of the month but do not know how long, and in this month the blood flows for a month. So the law is: The beginning of the monthsure menstruation, and for the next day there is the possibility of menstruation or not.

\subsection{Analyzing Rule of Haid and Istihadhah as Knowledge for Forward Chaining}

Forward Chaining is one of rule based algorithm that give the best decision or answer or conclusion from the facts (represented by rules). That rules is to be knowledge base for system to learn every facts that given. The mechanism of the forward chaining begins by added a set of facts into memory, then matching those facts to the IF part of the IF-THEN rules. If there is a fact that matches the IF section, then the rule is executed. When a rule is executed, a new fact (THEN part) is added to the database. Each time the matching starts from the top rule. Each rule can only be executed once. The matching process stops when there is no more executable rule or has reached a goal or no longer a rule whose premise matches the with the fact. Searching technique that can be used for forward chaining among others, depth-first search, breadth-first search, and best-first search. In this research we used depth-first search because of the rules are not too many and according to the needs of identifying menstruation and istihadhah.

Based on the explanation about mentruation and istihadhah above, we have 5 variables or parameters that influence identification process. Then, we have 7 categories as a result of identification of menstruation and istihadhah based on Quran-Hadith. Table I describes about code of variables and result, " $\mathrm{V}$ " for variables and " $\mathrm{H}$ " for result. Then Table II describes about relationship between variables and results that can be represented by decision tree (described in Fig. 1) and rules (describes in Table III).

Table 1. Code of Variables and Result of Haid and Istihadhah

\begin{tabular}{|c|l|}
\hline Code & \multicolumn{1}{|c|}{ Descriptions } \\
\hline V1 & It has been mentruation \\
\hline V2 & Know the characters of blood \\
\hline V3 & Understand the terms of good and bad about menstruation \\
\hline V4 & Remember the menstrual duration. \\
\hline V5 & Remember the first menstrual time \\
\hline H1 & MubtadiahMumayyizah \\
\hline H2 & MubtadiahGhoiruMumayyizah \\
\hline H3 & Mu'tadahMumayyizah \\
\hline H4 & $\begin{array}{l}\text { Mu'tadahGhoiruMumayyizahDzakirotun } \mathrm{Li} \\
\text { AdatihaQodronWaWaqtan }\end{array}$ \\
\hline H5 & $\begin{array}{l}\text { Mu'tadahWhoiruMumayyizahNasiyatun Li } \\
\text { AdatihaQodronWaWaqtan }\end{array}$ \\
\hline H6 & $\begin{array}{l}\text { Mu'tadahWhoiruMumayyizahDzakirotun Li AdatihaQodron La } \\
\text { Waqtan }\end{array}$ \\
\hline H7 & $\begin{array}{l}\text { Mu'tadahGhoiruMumayyizahDzakirotun Li AdatihaWaqtan La } \\
\text { Qodron }\end{array}$ \\
\hline
\end{tabular}


Table 2. The Relationship between Variables and Result of Haid and Istihadhah

\begin{tabular}{|c|l|l|l|l|l|}
\hline Code & V1 & V2 & V3 & V4 & V5 \\
\hline H1 & & $\checkmark$ & $\checkmark$ & & \\
\hline H2 & & $\checkmark$ & & & \\
\hline H3 & $\checkmark$ & $\checkmark$ & $\checkmark$ & & \\
\hline H4 & $\checkmark$ & $\checkmark$ & & $\checkmark$ & $\checkmark$ \\
\hline H5 & $\checkmark$ & $\checkmark$ & & & \\
\hline H6 & $\checkmark$ & $\checkmark$ & & $\checkmark$ & \\
\hline H7 & $\checkmark$ & $\checkmark$ & & & $\checkmark$ \\
\hline
\end{tabular}

Table 3. Rules Representation of Haid and Istihadhah Identification

\begin{tabular}{|c|c|}
\hline Rules & Descriptions \\
\hline R1 & IF V1 $=$ No AND V2=Yes AND V3 $=$ Yes THEN H1 \\
\hline R2 & IF V1=No AND V2=Yes AND V3=Yes THEN H1 \\
\hline R3 & IF V $1=$ No AND V $2=$ Yes AND V3 $=$ No THEN H 2 \\
\hline R4 & IF V1 $=$ Yes AND V2 $=$ Yes AND V3 $=$ No THEN H 2 \\
\hline R5 & IF V1=No AND V2=No AND V3=No THEN H2 \\
\hline R6 & IF V1 $=$ No AND NoV2 $=$ No AND V3 $=$ No THEN H 2 \\
\hline R7 & IF V2=No THEN V3=No, IF V3=No AND V1=NoTHEN H2 \\
\hline R8 & IF V3=No AND V1=No THEN H2 \\
\hline R9 & IF V1=Yes AND V2=Yes AND V3=Yes THEN H3 \\
\hline R10 & IF V1 $=$ Yes AND V2 $=$ Yes AND V $3=$ Yes THEN H3 \\
\hline R11 & $\begin{array}{l}\text { IF V1=Yes AND V2 }=\text { Yes AND V4=Yes AND V } 5=\text { Yes AND } \\
\mathrm{V} 3=\text { No THEN H } 4\end{array}$ \\
\hline R12 & $\begin{array}{l}\text { IF V1=Yes AND V2=Yes AND V4=Yes AND V5=Yes AND } \\
\text { V3=No THEN H4 }\end{array}$ \\
\hline R13 & $\begin{array}{l}\text { IF V1=Yes AND V4=Yes AND V5=Yes AND V3=No THEN } \\
\text { H4 }\end{array}$ \\
\hline R14 & $\begin{array}{l}\text { IF V1=Yes AND V4=Yes AND V5=Yes AND V2=NoAND } \\
\text { V3=No THEN H4 }\end{array}$ \\
\hline R15 & $\begin{array}{l}\text { IF V2=No THEN V3=No, IF V3=No AND V1=Yes AND } \\
\text { V4=Yes AND V5=Yes THEN H4 }\end{array}$ \\
\hline R16 & $\begin{array}{l}\text { IF V2=No THEN V3=No, IF V3=No AND V1=Yes AND } \\
\text { V4=Yes AND V5=Yes THEN H4 }\end{array}$ \\
\hline R17 & $\begin{array}{l}\text { IF V1=Yes AND V2=Yes AND V3=No AND V4=No AND } \\
\text { V5=No THEN H5 }\end{array}$ \\
\hline R18 & $\begin{array}{l}\text { IF V1=Yes AND V2=Yes AND V3=No AND V4=No AND } \\
\text { V5=No THEN H5 }\end{array}$ \\
\hline R19 & $\begin{array}{l}\text { IF V1=Yes AND V2=No AND V3=No AND V4=No AND } \\
\text { V5=No THEN H5 }\end{array}$ \\
\hline $\mathrm{R} 20$ & $\begin{array}{l}\text { IF V1=Yes AND V2=No AND V3=No AND V4=No AND } \\
\text { V5=No THEN H5 }\end{array}$ \\
\hline R21 & $\begin{array}{l}\text { IF V2=No THEN V3=No, IF V3=No AND V1=Yes AND } \\
\text { V4=No AND V5=No THEN H5 }\end{array}$ \\
\hline R22 & $\begin{array}{l}\text { IF V2=No THEN V3=No, IF V3=No AND V1=Yes AND } \\
\text { V4=No AND V5=No THEN H5 }\end{array}$ \\
\hline R23 & $\begin{array}{l}\text { IF V1=Yes AND V2=Yes AND V4=Yes AND V3=No AND } \\
\text { V5=No THEN H6 }\end{array}$ \\
\hline R24 & $\begin{array}{l}\text { IF V1=Yes AND V2=Yes AND V4=Yes AND V3=No AND } \\
\text { V5=No THEN H6 }\end{array}$ \\
\hline R25 & $\begin{array}{l}\text { IF V1=Yes AND V4=Yes AND V2=No AND V3=No AND } \\
\text { V5=No THEN H6 }\end{array}$ \\
\hline R26 & $\begin{array}{l}\text { IF V1=Yes AND V4=Yes AND V2=NoV3=No AND V5=No } \\
\text { THEN H6 }\end{array}$ \\
\hline R27 & $\begin{array}{l}\text { IF V2=No THEN V3=No, IF V3=No AND V1 AND V4 AND } \\
\text { V5=No THEN H6 }\end{array}$ \\
\hline
\end{tabular}




\begin{tabular}{|c|l|}
\hline Rules & \multicolumn{1}{|c|}{ Descriptions } \\
\hline R28 & $\begin{array}{l}\text { IF V2=No THEN V3=No, IF V3=No AND V1=Yes AND } \\
\text { V4=Yes AND V5=No THEN H6 }\end{array}$ \\
\hline R29 & $\begin{array}{l}\text { IF V1=Yes AND V2=Yes AND V5=Yes AND V3=No AND } \\
\text { V4=No THEN H7 }\end{array}$ \\
\hline R30 & $\begin{array}{l}\text { IF V1=Yes AND V2=Yes AND V5=Yes AND V3=No AND } \\
\text { V4=No THEN H7 }\end{array}$ \\
\hline R31 & $\begin{array}{l}\text { IF V1=Yes AND V5=Yes AND V2=No AND V3=No AND } \\
\text { V4=No THEN H7 }\end{array}$ \\
\hline R32 & $\begin{array}{l}\text { IF V1=Yes AND V5=Yes AND V2=No AND V3=No AND } \\
\text { V4=No THEN H7 }\end{array}$ \\
\hline R33 & $\begin{array}{l}\text { IF V2=No THEN V3=No, IF V3=No AND V1=Yes AND } \\
\text { V5=Yes AND V4=No THEN H7 }\end{array}$ \\
\hline R34 & $\begin{array}{l}\text { IF V2=No THEN V3=No, IF V3=No AND V1=Yes AND } \\
\text { V5=Yes AND V4=No THEN H7 }\end{array}$ \\
\hline
\end{tabular}

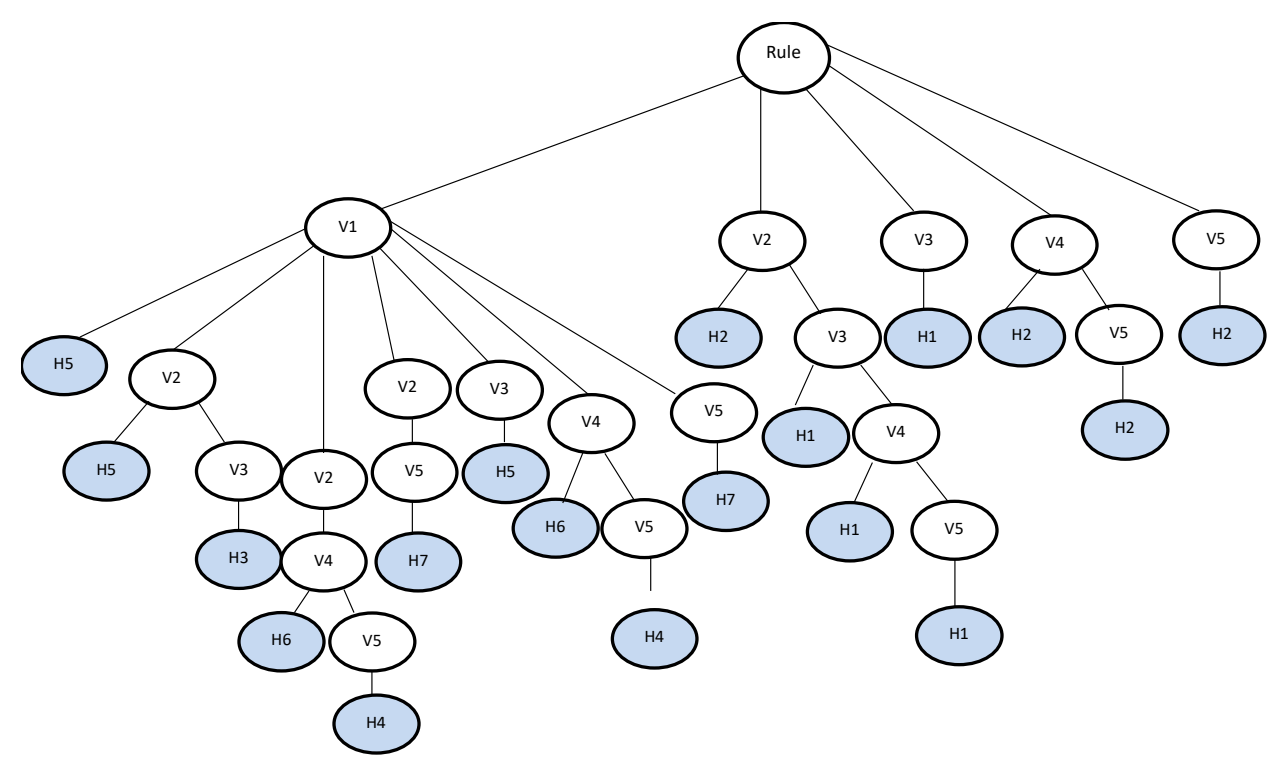

Figure 1. Decision tree representation of Haid and Istihadhah identification

Table 4. Result of Haid and Istihadhah Experiment

\begin{tabular}{|c|c|c|c|c|c|c|c|c|c|c|c|c|c|c|}
\hline \multirow[b]{2}{*}{ No } & \multicolumn{5}{|c|}{ Variables } & \multicolumn{7}{|c|}{ Result by System } & \multirow{2}{*}{ Manual } & \multirow{2}{*}{ Keterangan } \\
\hline & V1 & V2 & V3 & V4 & V5 & $\mathrm{H1}$ & $\mathrm{H} 2$ & $\mathrm{H} 3$ & $\mathrm{H} 4$ & H5 & H6 & $\mathrm{H} 7$ & & \\
\hline 1 & YES & YES & YES & $\mathrm{NO}$ & $\mathrm{NO}$ & & & $\checkmark$ & & & & & $\mathrm{H} 3$ & Correct \\
\hline 2 & YES & $\mathrm{NO}$ & NO & $\mathrm{NO}$ & YES & & & & & & & $\checkmark$ & $\mathrm{H} 7$ & Correct \\
\hline 3 & YES & $\mathrm{NO}$ & $\mathrm{NO}$ & YES & YES & & & & $\checkmark$ & & & & $\mathrm{H} 4$ & Correct \\
\hline 4 & YES & NO & NO & YES & $\mathrm{NO}$ & & & & & & $\checkmark$ & & H6 & Correct \\
\hline
\end{tabular}




\begin{tabular}{|c|c|c|c|c|c|c|c|c|c|c|c|c|c|c|}
\hline 5 & YES & YES & YES & $\mathrm{NO}$ & YES & & & $\checkmark$ & & & & & H3 & Correct \\
\hline 6 & $\mathrm{NO}$ & YES & $\mathrm{NO}$ & YES & YES & & $\checkmark$ & & & & & & $\mathrm{H} 2$ & Correct \\
\hline 7 & YES & YES & YES & YES & NO & & & $\checkmark$ & & & & & Unidentified & $\begin{array}{c}\text { Not } \\
\text { Correct }\end{array}$ \\
\hline 8 & $\mathrm{NO}$ & NO & $\mathrm{NO}$ & YES & $\mathrm{NO}$ & & $\checkmark$ & & & & & & $\mathrm{H} 2$ & Correct \\
\hline 9 & NO & YES & YES & YES & NO & $\checkmark$ & & & & & & & H1 & Correct \\
\hline 10 & $\mathrm{NO}$ & YES & YES & $\mathrm{NO}$ & NO & $\checkmark$ & & & & & & & H1 & Correct \\
\hline 11 & $\mathrm{NO}$ & $\mathrm{NO}$ & NO & YES & YES & & $\checkmark$ & & & & & & $\mathrm{H} 2$ & Correct \\
\hline 12 & YES & YES & YES & NO & $\mathrm{NO}$ & & & $\checkmark$ & & & & & $\mathrm{H} 3$ & Correct \\
\hline 13 & YES & $\mathrm{NO}$ & NO & $\mathrm{NO}$ & $\mathrm{NO}$ & & & & & $\checkmark$ & & & H5 & Correct \\
\hline 14 & $\mathrm{NO}$ & YES & YES & $\mathrm{NO}$ & YES & $\checkmark$ & & & & & & & $\mathrm{H} 1$ & Correct \\
\hline 15 & YES & YES & YES & $\mathrm{NO}$ & $\mathrm{NO}$ & & & $\checkmark$ & & & & & H3 & Correct \\
\hline 16 & YES & NO & YES & NO & YES & & & & & & & $\checkmark$ & Unidentified & $\begin{array}{c}\text { Not } \\
\text { Correct }\end{array}$ \\
\hline 17 & YES & YES & NO & YES & NO & & & & & & $\checkmark$ & & Unidentified & $\begin{array}{c}\text { Not } \\
\text { Correct }\end{array}$ \\
\hline 18 & NO & YES & YES & YES & YES & $\checkmark$ & & & & & & & H1 & Correct \\
\hline 19 & NO & $\mathrm{NO}$ & NO & $\mathrm{NO}$ & YES & & $\checkmark$ & & & & & & $\mathrm{H} 2$ & Correct \\
\hline 20 & YES & $\mathrm{NO}$ & $\mathrm{NO}$ & $\mathrm{NO}$ & $\mathrm{NO}$ & & & & & $\checkmark$ & & & $\mathrm{H} 5$ & Correct \\
\hline 21 & YES & YES & NO & $\mathrm{NO}$ & $\mathrm{NO}$ & & & & & $\checkmark$ & & & $\mathrm{H} 5$ & Correct \\
\hline 22 & YES & YES & YES & YES & NO & & & $\checkmark$ & & & & & Unidentified & $\begin{array}{c}\text { Not } \\
\text { Correct }\end{array}$ \\
\hline 23 & $\mathrm{NO}$ & YES & $\mathrm{NO}$ & $\mathrm{NO}$ & $\mathrm{NO}$ & & $\checkmark$ & & & & & & $\mathrm{H} 2$ & Correct \\
\hline 24 & $\mathrm{NO}$ & $\mathrm{NO}$ & YES & $\mathrm{NO}$ & $\mathrm{NO}$ & $\checkmark$ & & & & & & & H1 & Correct \\
\hline 25 & YES & YES & NO & YES & YES & & & & $\checkmark$ & & & & $\mathrm{H} 4$ & Correct \\
\hline 26 & YES & YES & $\mathrm{NO}$ & $\mathrm{NO}$ & YES & & & & & & & $\checkmark$ & $\mathrm{H} 7$ & Correct \\
\hline 27 & YES & $\mathrm{NO}$ & YES & NO & $\mathrm{NO}$ & & & & & $\checkmark$ & & & $\mathrm{H} 5$ & Correct \\
\hline 28 & YES & NO & NO & YES & NO & & & & & & $\checkmark$ & & H6 & Correct \\
\hline 29 & YES & NO & $\mathrm{NO}$ & YES & YES & & & & $\checkmark$ & & & & $\mathrm{H} 4$ & Correct \\
\hline 30 & $\mathrm{NO}$ & NO & YES & YES & $\mathrm{NO}$ & & $\checkmark$ & & & & & & $\mathrm{H} 2$ & Correct \\
\hline 31 & YES & NO & NO & YES & NO & & & & & & $\checkmark$ & & H6 & Correct \\
\hline 32 & YES & YES & $\mathrm{NO}$ & YES & $\mathrm{NO}$ & & & & & & $\checkmark$ & & H6 & Correct \\
\hline 33 & $\mathrm{NO}$ & YES & $\mathrm{NO}$ & $\mathrm{NO}$ & $\mathrm{NO}$ & & $\checkmark$ & & & & & & $\mathrm{H} 2$ & Correct \\
\hline 34 & YES & $\mathrm{NO}$ & YES & YES & $\mathrm{NO}$ & & & & & & $\checkmark$ & & H6 & Correct \\
\hline 35 & $\mathrm{NO}$ & YES & $\mathrm{NO}$ & $\mathrm{NO}$ & YES & $\checkmark$ & & & & & & & H1 & Correct \\
\hline 36 & YES & YES & NO & YES & NO & & & & & & $\checkmark$ & & $\mathrm{H} 6$ & Correct \\
\hline 37 & YES & YES & YES & YES & YES & & & $\checkmark$ & & & & & Unidentified & $\begin{array}{c}\text { Not } \\
\text { Correct }\end{array}$ \\
\hline 38 & NO & YES & YES & $\mathrm{NO}$ & YES & $\checkmark$ & & & & & & & $\mathrm{H} 1$ & Correct \\
\hline 39 & $\mathrm{NO}$ & $\mathrm{NO}$ & NO & YES & $\mathrm{NO}$ & & $\checkmark$ & & & & & & $\mathrm{H} 2$ & Correct \\
\hline 40 & YES & YES & NO & NO & YES & & & & & & & $\checkmark$ & $\mathrm{H} 7$ & Correct \\
\hline 41 & YES & NO & NO & YES & YES & & & & $\checkmark$ & & & & $\mathrm{H} 4$ & Correct \\
\hline 42 & NO & NO & NO & NO & NO & & $\checkmark$ & & & & & & Unidentified & $\begin{array}{c}\text { Not } \\
\text { Correct }\end{array}$ \\
\hline 43 & $\mathrm{NO}$ & YES & $\mathrm{NO}$ & YES & $\mathrm{NO}$ & & $\checkmark$ & & & & & & $\mathrm{H} 2$ & Correct \\
\hline 44 & $\mathrm{NO}$ & YES & YES & $\mathrm{NO}$ & $\mathrm{NO}$ & $\checkmark$ & & & & & & & H1 & Correct \\
\hline 45 & NO & $\mathrm{NO}$ & YES & YES & $\mathrm{NO}$ & & $\checkmark$ & & & & & & $\mathrm{H} 2$ & Correct \\
\hline 46 & NO & YES & $\mathrm{NO}$ & $\mathrm{NO}$ & YES & & $\checkmark$ & & & & & & Unidentified & $\begin{array}{c}\text { Not } \\
\text { Correct }\end{array}$ \\
\hline 47 & $\mathrm{NO}$ & NO & $\mathrm{NO}$ & YES & YES & & $\checkmark$ & & & & & & $\mathrm{H} 2$ & Correct \\
\hline 48 & NO & YES & YES & YES & NO & $\checkmark$ & & & & & & & $\mathrm{H} 1$ & Correct \\
\hline 49 & NO & $\mathrm{NO}$ & YES & NO & YES & & $\checkmark$ & & & & & & $\mathrm{H} 2$ & Correct \\
\hline 50 & YES & YES & NO & NO & YES & & & & & & & $\checkmark$ & $\mathrm{H} 7$ & Correct \\
\hline
\end{tabular}

\subsection{Software Development and Evaluation}

We built a web-based application to test whether the Forward Chaining algorithm that we used to identify menstruation and istihadhah is well enough and able to provide an accurate conclusion. Using 5 variables or input parameters, 7 result groups, and 34 rules, Forward Chaining successfully identified menstruation and istihadhah with an accuracy of about $86 \%$. This accuracy is obtained from 50 case studies of women's menstrual experience (as 
respondents). Using a simple statistical formula, 43of 50 cases can be identified by the system appropriately, while the other 7 are incorrect. This is because some of the possibilities error, such as in the process of identifying input variables is wrong or the absence of results that refer to the answer. This proves that Forward Chaining depends heavily on complete or incomplete, correct or incorrect rules that defined as its knowledge base.Table IV shows the result of experiment of this study.

Blood color analysis can be performed to identify menstruation oristihadhah, further development of the system may involve the introduction of color as a database to express menstruation or istihadhah. One model that can be developed is software that presents information in the form of multi-media, especially images. Through the use of multimedia, in addition based on the time of menstruation, women can learn to distinguish menstruation and istihadhah based on blood color. In education, multimedia can be used as instructional media or personal learning media[29]. The use of multimedia for instructions has enhancing the learning effectiveness of learning [30], enhancing learning motivation[31], and improving the level of understanding [32].Further development that can be developed is to convey various variants of information from women fiqh, given the fatwa of various scholars have a variety of styles.

\section{Conclusion}

Haid and istihadhah is important knowledge for woman, especially for Muslim because it deals with what should and should not be done during menstruation. Not a few women are confused whether the blood coming out of their wombs is menstrual blood or not. This study helps solve the problem, to identify menstruation and istihadhah by applying the Forward Chaining algorithm. Experimental results show that Forward Chaining is able to identify menstruation and istihadhah well. The error in the identification due to the rules that do not accommodate the possibility of a particular case. So for future research, rules need to be analyzed and replenished so that all possible cases can be resolved. In addition, this research can be developed into expert system research or data mining so that more powerful.

\section{References}

[1] S. S. bin F. bin A. Al-Fauzan, Diktat Ahkamun Nisa'. Al-Qowam, 2015.

[2] N. K. Tawang, B. Ibrahim, and N. Daud, "Amalan Pengurusan Kebersihan Darah-darah Wanita Menurut Islam,” J. Islam Dan Masy. Kontemporari, 2016.

[3] A. Pamoragung, K. Suryadi, and M. A. Ramdhani, "Enhancing the implementation of eGovernment in indonesia through the high-quality of virtual community and knowledge portal," in Proceedings of the European Conference on e-Government, ECEG, 2006, pp. 341-348.

[4] D. S. Maylawati, W. Darmalaksana, and M. A. Ramdhani, "Systematic Design of Expert System Using Unified Modelling Language," IOP Conf. Ser. Mater. Sci. Eng., vol. 288, no. 1, p. 012047, 2018.

[5] H. Aulawi, M. A. Ramdhani, C. Slamet, H. Ainissyifa, and W. Darmalaksana, "Functional Need Analysis of Knowledge Portal Design in Higher Education Institution," Int. Soft Comput., vol. 12, no. 2, pp. 132-141, 2017.

[6] M. A. Ramdhani, Metodologi Penelitian untuk Riset Teknologi Informasi. Bandung: UIN Sunan Gunung Djati Bandung, 2013. 
[7] C. Slamet, R. Andrian, D. S. Maylawati, W. Darmalaksana, and M. A. Ramdhani, "Web Scraping and Naïve Bayes Classification for Job Search Engine," vol. 288, no. 1, pp. 1-7, 2018.

[8] Y. A. Gerhana, W. B. Zulfikar, A. H. Ramdani, and M. A. Ramdhani, "Implementation of Nearest Neighbor using HSV to Identify Skin Disease," IOP Conf. Ser. Mater. Sci. Eng., vol. 288, no. 1, p. 0121531234567890 Implementation, 2018.

[9] A. Rahman, C. Slamet, W. Darmalaksana, Y. A. Gerhana, and M. A. Ramdhani, "Expert System for Deciding a Solution of Mechanical Failure in a Car using Case-based Reasoning," IOP Conf. Ser. Mater. Sci. Eng., vol. 288, no. 1, p. 012011, 2018.

[10] C. Slamet, A. Rahman, M. A. Ramdhani, and W. Darmalaksana, "Clustering the Verses of the Holy Qur'an Using K-Means Algorithm,” Asian J. Inf. Technol., vol. 15, no. 24, pp. 5159-5162, 2016.

[11] D. S. Maylawati, M. A. Ramdhani, W. B. Zulfikar, I. Taufik, and W. Darmalaksana, "Expert system for predicting the early pregnancy with disorders using artificial neural network," 2017 th Int. Conf. Cyber IT Serv. Manag. CITSM 2017, 2017.

[12] W. B. Zulfikar, Jumadi, P. K. Prasetyo, and M. A. Ramdhani, "Implementation of Mamdani Fuzzy Method in Employee Promotion System," IOP Conf. Ser. Mater. Sci. Eng., vol. 288, no. 1, p. 012147,2018

[13] D. S. A. Maylawati, M. A. Ramdhani, A. Rahman, and W. Darmalaksana, "Incremental technique with set of frequent word item sets for mining large Indonesian text data," in 20175 th International Conference on Cyber and IT Service Management, CITSM 2017, 2017.

[14] A. Taofik, N. Ismail, Y. A. Gerhana, K. Komarujaman, and M. A. Ramdhani, "Design of Smart System to Detect Ripeness of Tomato and Chili with New Approach in Data Acquisition," in IOP Conference Series: Materials Science and Engineering, 2018, vol. 288, no. 1, p. 012018.

[15] I. Akil, "Analisa Efektifitas Metode Forward Chaining Dan Backward Chaining," J. Pilar Nusa Mandiri, 2017.

[16] A. Al-Ajlan, "The Comparison between Forward and Backward Chaining," Int. J. Mach. Learn. Comput., 2015.

[17] Y. Septiana, D. Kurniadi, and A. Mulyani, "Perancangan Program Aplikasi Faraidh sebagai Sistem Pendukung Keputusan Pembagian Harta Waris Berorientasi Solver," J. Algoritm., vol. 14, no. 2, pp. 474-480, 2017.

[18] M. Yunus and S. Setyowibowo, "Aplikasi sistem pendukung keputusan diagnosa penyakit paru- paru dengan metode forward chaining," Apl. Sist. pendukung keputusan diagnosa penyakit paru- paru dengan Metod. Forw. Chain., 2011.

[19] D. Minarni, I. G. T. Isa, and A. Yanik, "Aplikasi Bagi Waris Islam dengan Metode Forward Chaining berbasis Web," J. Online Inform., 2018.

[20] Ichsan Taufik, “Aplikasi Diagnosa Gangguan Kepribadian,” J. Ilm. Tek. Inform., 2014.

[21] L. Perdana, D. Nugroho, and Kustanto, "Sistem Pakar Untuk Diagnosis Penyakit Ginjal Dengan Metode Forward Chaining," J. TIKomSiN, 2013.

[22] S. Khosyi'Ah, M. Irfan, D. S. Maylawati, and O. S. Mukhlas, "Analysis of Rules for Islamic Inheritance Law in Indonesia Using Hybrid Rule Based Learning," in IOP Conference Series: Materials Science and Engineering, 2018, vol. 288, no. 1.

[23] D. Mahdjoubi, "The Linear Model of Technological Innovation: Background and Taxonomy," The Atlas of Innovation. 1997.

[24] D. Sa, M. A. Ramdhani, and A. S. Amin, "Tracing the Linkage of Several Unified Modelling Language Diagrams in Software Modelling Based on Best Practices," vol. 7, pp. 776-780, 2018.

[25] M. A. Ramdhani, D. S. Maylawati, A. S. Amin, and H. Aulawi, "Requirements Elicitation in Software Engineering," Int. J. Eng. Technol., vol. 7, no. 2.29, pp. 772-775, 2018.

[26] P. Coad and E. Yourdon, Object-Oriented Design, 1st ed. Yourdon Computing Press Series, 1990.

[27] P. Coad and E. Yourdon, "Object Oriented Analysis," Comput. Aided Archit. Des., 1991. 
[28] B. P. Fatimah, "Penerapan Metode Forward Chaining untuk Mengidentifikasi Jenis-Jenis Haid dan Istihadhah," Bandung, 2017.

[29] I. Farida, I. Helsy, I. Fitriani, and M. A. Ramdhani, "Learning Material of Chemistry in High School Using Multiple Representations," IOP Conf. Ser. Mater. Sci. Eng., vol. 288, no. 1, p. 012078, 2018.

[30] F. S. Irwansyah, Y. M. Yusuf, I. Farida, and M. A. Ramdhani, "Augmented Reality (AR) Technology on the Android Operating System in Chemistry Learning," IOP Conf. Ser. Mater. Sci. Eng., vol. 288, no. 1, p. 012068, 2018.

[31] Sari, F. S. Irwansyah, I. Farida, and M. A. Ramdhani, "Using Android-Based Educational Game for Learning Colloid Material Using Android-Based Educational Game for Learning Colloid Material," J. Phys. Conf. Ser., vol. 895, no. 1, p. 012012, 2017.

[32] I. Helsy, Maryamah, I. Farida, and M. A. Ramdhani, "Volta-Based Cells Materials Chemical Multiple Representation to Improve Ability of Student Representation," J. Phys. Conf. Ser., vol. 895, no. 1, p. 012010, 2017. 